\title{
Homeward bound: canopy cover and species identity influence non-breeding season homing success and speed in forest birds
}

\author{
Jin Bai ${ }^{1^{*} \mathbb{D}}$, Chelsea A. Weitekamp ${ }^{2}$, Kelly Frye ${ }^{1}$ and Kathryn E. Sieving ${ }^{1}$
}

\begin{abstract}
Background: Efficient and safe movement is fundamental for wild birds to thrive in their environments. For arboreal forest animals, especially birds, canopy cover has a large impact on birds' daily movements and is a crucial component of conservation strategies seeking to retain avian population in disturbed or urban habitats.

Methods: We translocated woodland bird species utilizing different forest strata during two non-breeding seasons in Gainesville, FL, USA. We used linear model and generalized linear model to examine the effects of canopy cover and species identity on homing success and speed.

Results: Among our study species of Tufted Titmouse (Baeolophus bicolor), Carolina Chickadee (Poecile carolinensis), and Northern Cardinal (Cardinalis cardinalis), we found that Carolina Chickadees and Tufted Titmice were more likely to return than Northern Cardinals. Among birds that successfully returned, homing speed is significantly affected by forest canopy cover and species identity (titmice had higher homing speed than cardinals). Birds return much faster in landscape with higher canopy cover.

Conclusions: This study presented evidence of species identity's effect on homing success and speed in common feeder bird species in Southeast US and provided further evidence that bird movements in the suburban land cover are constrained by low canopy cover.
\end{abstract}

Keywords: Forest bird movement, Forest canopy cover, Homing behaviour, Non-breeding season, Site fidelity

\section{Background}

Habitat loss and fragmentation are of central concern for the conservation of North American forest birds, since declines in their populations have been associated with habitat loss and fragmentation (Peterjohn 2003; Valiela and Martinetto 2007; Pimm and Brooks 2013; Hindmarch et al. 2017). Identifying aspects of habitat change that have the greatest effects on survival, reproduction, and movement of forest birds will be informative to conservation efforts (Zollner and Lima 2005). For example,

*Correspondence: jbai5@ncsu.edu

${ }^{1}$ Wildlife Ecology and Conservation, University of Florida, Gainesville, FL, USA

Full list of author information is available at the end of the article increased forest edge has been associated with fragmentation and smaller patch size, and it increases the occurrence of nest predation and lower reproductive success, which contributes to bird population declines (Hoover et al. 1995; Chalfoun et al. 2002). In addition, birds traveling through fragmented landscapes suffer an increase in energy expenditure and longer travel times due to their reluctance to cross open areas (Lima 1993; Sieving et al. 1996; Zollner and Lima 2005) and instead prefer to take detours within forest corridors (St. Clair et al. 1998) to avoid an increased predation risk. One of the animal movements that may encounter this reluctance is homing behavior, which refers to "the ability of certain animals to return to a given place when displaced from it, often over great distances." (The Editors of Encyclopaedia Britannica 
2017). Non-migratory birds have strong winter fidelity, but it is less well-known for canopy cover effect on homing behavior (Krištín and Kaňuch 2017). This study was undertaken to help further understand the homing behavior of non-migratory birds during a non-breeding season in an urban environment.

Forest birds are affected in varying degrees by landscape changes depending on their physical and behavioral characteristics (Newbold et al. 2013). Identifying the characteristics of birds most susceptible to habitat change will also aid conservation efforts (Schlaepfer et al. 2002). A generalist species is able to thrive in a wide variety of environmental conditions and can make use of a variety of resources. A specialist species with limited diet can only thrive in a narrow range of environmental conditions (Royle 2012; Begon et al. 2014). Birds that are specialists are more reluctant than generalists to cross habitat gaps during playback experiments (Sieving et al. 1996; Rail et al. 1997) and demonstrate longer homing times after translocations due to increased use of detour routes (Gillies and St. Clair 2008). Individual species also have varying threshold distances at which they are willing to cross gaps (St. Clair et al. 1998) and different perceptual ranges for which they can perceive the fragmented landscape (Lima and Zollner 1996). All of these factors may affect their willingness to, and speed of, travel through fragmented landscapes.

We undertook this study to understand how canopy cover and species identity in an urbanized area affect birds' homing success and speed in order to contribute information concerning urban green space planning. We had two specific objectives: (1) to characterize variation in non-breeding season homing propensity (success and speed of return) among common bird species, and (2) to test for the effects of canopy cover on the homing success and speed of translocated birds. Similar to previous studies, translocating individual birds away from their home ranges were used to control the motivation to home, the distance traveled, and the percentage of forest cover in the homing path (Bélisle et al. 2001; Blumstein and Fernandez-Juricic 2010). Unlike most other studies, however, translocations were performed during the non-breeding season because homing propensity in this period was of particular interest to us (Odum 1941; Benvenuti and Ioalè 1980). Past studies that conducted homing experiments during the non-breeding season have explored how age group, spatial memory, species identity, sex, and forest type influence avian homing behavior (Benvenuti and Ioalè 1980; Baccetti et al. 1995; Keiser et al. 2005; Krištín and Kaňuch 2017). However, little is known about the forest canopy cover effect on avian homing behavior in an urban environment where urban forests are fragmented by large roads and urban developments. Based on the contrasting biology of the different species and previous work, we made some general predictions: (1) All species (Carolina Chickadee Poecile carolinensis, Tufted Titmouse Baeolophus bicolor and Northern Cardinal Cardinalis cardinalis) should demonstrate some level (at least $30 \%$ ) of winter homing success because of the tendency toward winter territoriality is a characteristic of passerines (Tompkins 1933; Salomonson and Balda 1977; Holmes et al. 1989; Krištín and Kaňuch 2017), (2) homing speed of all species should increase with an increase in the percentage of forest cover over the homing path (Bélisle et al. 2001), and (3) Paridae species (chickadees and titmice, also refer as parid), as foraging generalists and canopy-foragers, should return faster than Northern Cardinals (ground-foragers), which are thought to be less likely to cross gaps (Sieving and Karr 1997; Miller and Cale 2000; Vergara and Simonetti 2006).

\section{Methods}

\section{Study area and trap sites}

Six different trap locations were established around Gainesville, Florida, USA (Fig. 1). Four of the sites were on the University of Florida campus. One site was located in a Gainesville neighborhood (4 $\mathrm{km} \mathrm{NE}$ of campus) and the other was at the USDA/APHIS Florida Field station (6 km east of campus). For each capture location, a minimum of two translocation drop-off sites were utilized to sample a diversity of canopy covers in return paths.

\section{Capture and translocation methods}

Three study species, Tufted Titmouse, Carolina Chickadee, and Northern Cardinal were captured and translocated. These common bird species are all resident birds and maintain territoriality year-round. Birds were caught using walk-in wire treadle traps on top of platform bird feeders during non-breeding seasons (September-February) in 2009 and 2011 (same bird feeder were used from study of Hetrick and Sieving 2012). Then birds were translocated from 0.3 to $1.6 \mathrm{~km}$ away, with the majority of translocations occurring at $1 \mathrm{~km}$ distance. The traps were baited with safflower and black oil sunflower seeds and left open for two weeks prior to trapping. Visitation to feeder traps was monitored during the pre-trapping periods to ensure that birds were frequently visiting the feeders. One feeder trap was established in each of six trapping locations in each year. Once captured, the birds were marked with unique color band combinations. Birds were then kept in individual cloth bags, during transport by car or bicycle, for less than one hour after capture (typically, times between capture and final release were less than 20-30 min). Birds were released near canopy cover to allow for safe perching immediately after release. The release time were from 8:00 am to $4: 00 \mathrm{pm}$. At the 


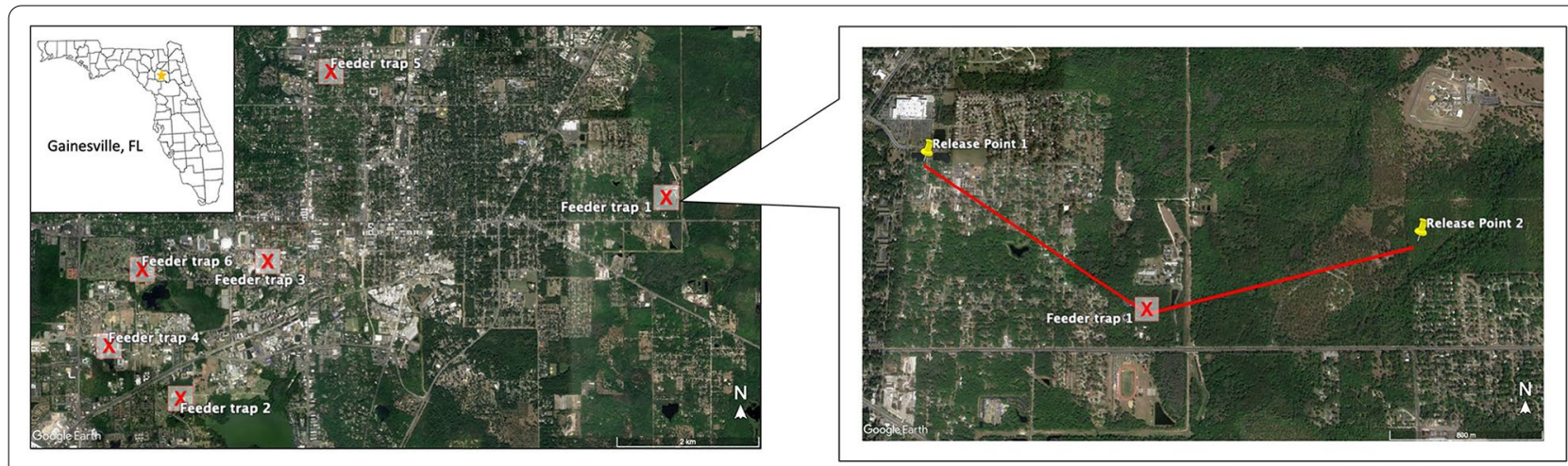

Fig. 1 Study location and sampling sites. The left map shows all six feeder trap locations within the city of Gainesville, Florida, USA. The right inset for one feeder trap, shows the contrasting translocation paths

beginning of translocation experiments, 4 short distance translocations (200-700 m) were performed to examine whether birds would return at all. Later, all translocations were generally longer $(1-1.6 \mathrm{~km})$. The known winter home range sizes of our study species are all less than one kilometer in width (CACH: $532 \mathrm{~m}$, NOCA: 420 m, TUTI: 914 m; Brewer 1961; Condee 1970; Ritchison and Omer 1990). This winter home range size is based on the maximum movement distance between two points within a territory. Thus, our translocation distances ensured that birds were released in unfamiliar territories.

\section{Canopy cover measurements}

The percent of canopy cover associated with the different homing paths was determined using Google Earth TM. We used the map image (year 2009) at $4 \mathrm{~km}$ eye altitude and overlaid a circle surrounding the translocation path with the same diameter as the straight-line path between the capture and release sites (Visual illustration in Additional file 1: Figure S1). The circular areas were overlaid with a grid containing the same density of squares (incomplete squares are not used). The number of squares within the circular area that had visible tree canopy were counted and divided by the total number of gridded squares to obtain \% canopy cover. We used a circular area rather than a straight-line path to better predict the canopy cover of possible homing routes since birds were not tracked during their movement home and were likely to wander from the straight line (Duhl et al. 2012).

\section{Measure homing success and speed}

Each feeder trap was equipped with a motion sensitive camera (Audubon Bird Cam TM or Reconyx Rapidfire TM) that displayed the time and date on each picture, which allowed each homing bird to be identified by its unique markings following return to the feeder. We recorded whether an individual successfully returned or not $(1,0)$ by checking photos of birds at the capture feeder until a maximum of $800 \mathrm{~h}$ (33 days) had passed since release at the translocation site. If the individual was not photographed in that time, then it was counted as not returned (0). We utilized the time and date of release at the translocation site and the time and date of the first detection of the bird at the home feeder by the motion sensitive camera to determine the homing speed in hours. This method may underestimate both the number of birds that returned to capture sites, and their homing speeds, due to hesitancy to revisit the feeder where they were captured. However, given that high percentage of birds (66\%) clearly revisited the feeder's posttranslocation within 1 or 2 days of initial capture, we do not think that the returning proportion is seriously underestimated (given the long grace period we used)even trap-shy birds would have had time to recover. For more precise return measurement, combinations of cameras, radio-tracking with automated receivers, mistnetting, and systematic observational efforts utilizing territorial and mobbing playbacks at capture locations could enhance precision (Castellón and Sieving 2006; Desrochers et al. 2011; Villard and Haché 2012; Volpe et al. 2014; Jones et al. 2017; Krištín and Kaňuch 2017). Our method minimized impacts on the well-being of the birds (of interest to us) over these other methods, and our methods were standardized across sites and species. In any mark recapture methodology, precision is at issue. While we do not know how well our method performed relative to others, a methodological study of civet capture-recapture found that the use of camera traps with lures did not change animal movement patterns but did increase the number of captures over un-baited camera traps (Gerber et al. 2012). Perhaps, habituating the birds to a food lure prior to translocation insured a high probability of recapture detection post translocation. In any 
case, standardized methods of detection for three species that habitually visit feeders allowed us to make relative comparisons among species and return path conditions; precise homing frequencies were not the goal.

\section{Data analysis}

Statistical analyses using linear model (LM) and generalized linear model (GLM) were run in R (version 4.0.2). We ran two types of models: (1) to test how canopy cover, translocation distance, species identity, and release time influence homing success of our study species; (2) to test how those predictors influence homing speed of our study species. We used GLM-binomial for the homing success model and LM for the homing speed model. The homing speed variable (hours to return) in LM was log transformed to fit a normal distribution.

\section{Results}

A total of 71 translocations were performed of 3 different species (summarized in Table 1). An average of $66 \%$ of all birds were re-sighted at feeders in their home territory or capture site within 33 days. We found that Northern Cardinals were less likely to return than Carolina Chickadees (Coef $=1.847, \mathrm{SE}=0.932, p=0.048$; Table 2) and Tufted Titmice $(\mathrm{Coef}=1.718, \mathrm{SE}=0.648$, $p=0.008$; Table 2). Among individuals returned to the capture sites $(n=44)$, the percentage of canopy cover did influence homing speed; birds translocated in areas with higher tree canopy cover returned much faster (Coef $=-$ $0.531, \mathrm{SE}=0.196, p=0.010$; Table 2), and Tufted Titmice returned much faster than Northern Cardinals (Coef $=-$ 1.100, $\mathrm{SE}=0.440, p=0.017$; Table 2).

\section{Discussion}

Canopy cover positively influenced homing speed but not homing success. This suggests that a slower and more tortuous return necessitated by lower canopy cover (Bélisle et al. 2001) does not lessen the commitment to return. However, increased tree canopy cover does enhance the probability of crossing urban area for forest birds, which implied that higher canopy cover provides safer habitat for bird's movement (Shimazaki et al. 2017). Less forested landscapes present abundant high contrast boundaries and gaps containing 'hostile' matrix for forest animals (Lima 1993; Sieving et al 1996, 2004; Desrochers and Hannon 1997) where predation risk is higher (Cornelius et al. 2017). Birds may choose to move through habitat corridors, rather than across open gaps in the forest, even when a path through corridors significantly increases the distance of travel (St. Clair et al. 1998; Castellón and Sieving 2006). With increased distance comes, an increase in the cost of movement through increased risks from predation and energy expenditure (Baker and Rao 2004). Our findings are consistent with the existence of a trade-off between detouring through corridors and crossing gaps, but our study design did not allow

Table 1 Summary of homing translocations

\begin{tabular}{lllllc}
\hline Species & $\boldsymbol{N}$ & \% Canopy cover & Translocation distance & \% Return & Hours to return \\
\hline CACH & 11 & $42(32-73)$ & $1096(1000-1500)$ & 82 & $199(23-508)$ \\
NOCA & 29 & $55(26-73)$ & $1091(240-1500)$ & 45 & $248(11-705)$ \\
TUTI & 31 & $50(24-73)$ & $1090(240-1620)$ & 81 & $90(4-763)$ \\
Summary & 71 & $51(24-73)$ & $1092(240-1620)$ & 66 & $154(4-763)$ \\
\hline
\end{tabular}

$N$ represents the total number of translocations; \% Canopy cover represents the percentage of tree canopy cover for each translocation path; \% Return represents the percentage of translocated individuals returned to capture sites. Values of \% Canopy cover, Translocation distance, and Hours to return in the table are mean values with the minimum and maximum range in (). CACH represents Carolina Chickadee, NOCA represents Northern Cardinal, and TUTI represents Tufted Titmouse

Table 2 Summary of model outputs of homing success model and homing speed model

\begin{tabular}{|c|c|c|c|c|c|c|}
\hline \multirow[t]{2}{*}{ Variables } & \multicolumn{3}{|c|}{ Homing success model (GLM) } & \multicolumn{3}{|c|}{ Homing speed model (LM) } \\
\hline & Coef & Std. error & $p$ value & Coef & Std. error & $p$ value \\
\hline Intercept & -0.278 & 0.416 & 0.503 & 4.842 & 0.361 & $<0.001$ \\
\hline Species CACH & 1.847 & 0.932 & 0.048 & -0.228 & 0.589 & 0.700 \\
\hline Species TUTI & 1.718 & 0.648 & 0.008 & -1.100 & 0.440 & 0.017 \\
\hline$\%$ Canopy cover & 0.116 & 0.321 & 0.717 & -0.531 & 0.196 & 0.010 \\
\hline Translocation distance & -0.554 & 0.316 & 0.080 & 0.047 & 0.208 & 0.824 \\
\hline Release time & 0.142 & 0.313 & 0.651 & 0.303 & 0.202 & 0.141 \\
\hline
\end{tabular}

Coef. represents the estimated coefficients of each variable. Std. error represents standard error. \% Canopy cover represents the percentage of tree canopy cover for each translocation path. Intercept represents Northern Cardinal, CACH represents Carolina Chickadee, and TUTI represents Tufted Titmouse 
detailed description of behaviors actuating this trade-off. In this study we tested for forest cover effects within the potential return areas, and we could not test for effects of finer-scale configuration (e.g. corridor width or tortuosity; Bélisle et al. 2001; Gillies et al. 2011) of paths used by the birds. However, studies testing specific aspects of actual return paths in relation to homing success could yield very specific and useful prescriptions for configuring 'street tree' plantings within urban areas to lessen resistance to urban bird movements (Shimazaki et al. 2017; Wood and Esaian 2020).

We reported significant effects of species identity on homing success and speed. Among the species we sampled, titmice and chickadees returned more frequently compared to cardinals and they also return faster than cardinals. All three species are thought to be highly sedentary as adults and permanent residents on all purpose territories they defend in winter. However,cardinal winter movements in large flocks of cardinals may be more fluid than those of the parids in winter (Halkin and Linville 2020; Ritchison et al. 2020). In the center of the species' collective range, mass movements of both cardinals and parids may occur in response to winter weather patterns. Perhaps the biggest difference between cardinals and parids in winter mobility and philopatry derives from their microhabitat affiliations. Near-ground dwelling birds (e.g. cardinals) are more sensitive to fragmentation due to their ground-dwelling habits compared with titmice and chickadees (Sieving et al. 1996; Sieving and Karr 1997; Stratford and Stouffer 1999). Cardinals in our study concentrate their activities near-ground and the homing success was not greater than $50 \%$. The translocation paths we used led through complex and fragmented suburban landscapes that likely presented a variety of obstacles (e.g. Walmart parking lot) and alternative resources for cardinals (feeders) resulting in overall lower return success and speed. In a breeding season translocation study of 10 cardinals moved similar distances $(\sim 1.6$ $\mathrm{km}$; Evans et al. 2017) cardinal returns were $80 \%$, but return speeds were comparable to what we detected in similar suburban (heavily treed) habitat but were much longer in more intensely urban landscapes. In breeding season, birds should be more strongly tied to territory, so it is reasonable that return successes were higher in that study than ours.

We found that when translocated across complex suburban landscapes, common bird species consistently returned to their home territories, indicating that permanent resident forest birds can exhibit strong site fidelity during the non-breeding season. Familiarity with resources and local predators in a bird's home territory is thought to confer sufficient benefit to warrant the costs of non-breeding season homing (Desrochers et al. 1988;
Yoder et al. 2004). Non-breeding season conditions can magnify the value of stable or familiar food resources for year-round resident bird species (Berner and Grubb Jr 1985). Despite the fact that non-breeding season conditions in Northern Florida may seem relatively mild by comparison to the northern reaches of the study species' ranges, a productive territory is likely just as valuable for these birds. Especially in urban areas, predation risk is likely to be severe due to significant reductions in tree canopy density (Patterson et al. 2016) and a simultaneous influx of Sharp-shinned Hawks (Accipiter striatus), a common winter visitor that is absent the rest of the year (Roth et al. 2006; Farley et al. 2008; Contreras and Sieving 2011). Moreover, previous work in the study areas suggests that urban Accipiters may be more highly specialized on adult feeder birds (Malone et al. 2017) than rural hunting hawks. Finally, given the extended breeding season of southern birds, including 1-2 more broods per year than in the north, territory ownership in nonbreeding season likely minimizes intra-specific aggression experienced by resident birds during pairing and breeding season initiation, and this should also encourage non-breeding season homing behavior in displaced individuals (Brown 1963). Therefore, the advantages of keeping a stable and familiar non-breeding season territory with abundant resources for feeding and known escape locations for avoiding specialist predators should be significant for resident birds. The provision of reliably well-stocked feeders (food supplement), almost certainly enhanced the value of the territories to our study individuals, helping to overcome any energetic benefits of remaining near the release sites (Roth and Vetter 2008). However, we used feeder-birds specifically so that their motivation to home could be standardized in some way to enhance the comparison of relative propensity to home range. Whether or not feeders altered non-breeding season homing strength in our study would be worth addressing with further research utilizing non-supplemented birds.

Possible fates of the relatively small proportion of individuals that were not re-sighted in this study likely include the following. (1) Birds may encounter sufficiently high-quality resources on the return path to cause them to forsake returning to the original territory. For example, Northern Cardinals translocated with radio-transmitters in Illinois during winter largely did not return to their capture sites but stayed the winter at feeders they encountered close to their release sites (MP Ward, personal communications). (2) Birds may have been killed by predators on the route to their home territory. An abundance of passerine predators occurs in winter suburban habitats in Florida, from Red-shouldered Hawk (Buteo lineatus) and two Accipiter species to free-ranging 
domestic cats. (3) Some birds may have returned but remained undetected by us. (4) The status of a species' pair- and family-bonds in the non-breeding season may have influenced birds' motivation to return. For example, Paridae species maintain close year-round pair bonds and share winter territories with mates and extended family groups (Weisman 2007). In addition, we have observed close multi-year associations between marked titmouse and chickadee pairs at feeders, suggesting longterm interspecific flock associations. These strong social bonds that parids maintain could help explain why they returned so rapidly and consistently in our study compared to cardinals. Cardinals on the other hand are not known to maintain year-round pair bonds (Halkin and Linville 2020). (5) We did not attempt to precisely age the study individuals, in part because of the variance in reliability of available methods among our study species (Pyle 1997). Therefore, some translocated individuals could have been hatch-year birds that were either too inexperienced at navigating to get home and/or motivated to use the translocation as an opportunity to initiate natal dispersal. We note that at least two hatch-year titmice known to us did return quickly and successfully to their natal territories, suggesting that hatch-year birds are already good navigators by their first winter, but we have no estimate of the proportion of young birds translocated overall. (6) Sex may also influence homing behavior by various mechanisms (sex-biased dispersal, hormonal variation, etc.) but with the exception of cardinals, none of our species were easily identifiable as to sex. We currently have DNA-based data suggesting that body size is not a precise indicator of Paridae sex in Florida (KE Sieving, unpublished data) therefore we refrained from using that to test for sex effects. (7) Personality-based variation such as exploratory behavior may have accounted for homing speed and propensity variation within (Cornelius et al. 2017) or between species (Huang et al. 2016). (8) Cognitive and perceptual abilities may affect homing success and speed as well. In sum, we cannot estimate the relative importance of these alternatives (1-8) given our study design, but all are quite possible, and it is likely that interspecific and inter-individual variability in homing behavior was caused by multiple factors. The relative importance of all of the above influential factors, however, will be of interest in future determinations of how behavioral connectivity interacts with landscape change (Crooks and Sanjayan 2006; Koen et al. 2017).

\section{Conclusions}

We found that responses to translocation vary strongly by species, and Tufted Titmice and Carolina Chickadees were more likely to return than cardinals. Among birds returned, titmice also showed much higher homing speed than cardinals, which indicates the higher sensitivity to fragmented landscape from cardinals. Given the significant travel costs in fragmented landscapes, small additions in forest cover can significantly reduce the time needed for critical movements by forest-dwelling birds. Addition of forest cover at the scale of single land-owners in urban-suburban landscapes (Hostetler 2001), where most of our study species are abundant, could significantly improve conditions for non-breeding season home-range movements. Considerations of vegetative cover in urban and suburban landscapes should be made in conservation planning, not only for provision of movement habitat, but for provision of natural foods and functional nesting sites (Jokimäki and Huhta 2000; Castellón and Sieving 2006; López-Flores et al. 2009). Future studies could productively focus on identifying whether there are threshold levels of vegetative cover or connectivity that define hard limits on animal movement (Metzger and Décamps 1997; With and King 1999). Such landscape level measures could be useful for planning boards and developers of large tracts of land seeking sustainable ecological designs (Leitāo and Ahern 2002). Habitat loss has repeatedly been shown to affect breeding movements (Norris and Stutchbury 2001), dispersal of young birds (Baguette and van Dyck 2007), and we have shown that non-breeding season movements of permanent resident birds are similarly affected.

\section{Supplementary Information}

The online version contains supplementary material available at https://doi. org/10.1186/s40657-021-00260-x.

Additional file 1: Figure S1. Illustration of the canopy cover measurements.

Additional file 2. Dataset.

\section{Acknowledgements}

We thank M. Avery and K. Keacher for support and field site use of the USDA/ APHIS Florida Field Station. We also thank the students in the Sieving lab for reviews of previous versions of this manuscript and P. Huang for field assistance.

\section{Authors' contributions}

KES designed the study. CAW and KF collected the data. JB performed the data analysis. All authors wrote the manuscript. JB revised the manuscript sustainably. All authors read and approved the final manuscript.

\section{Funding}

Financial support for this study was provided by University Scholars Program awards to CAW and KF at the University of Florida.

Availability of data and materials

All data generated or analyzed during this study are included in this published article (Additional file 2: Dataset). 


\section{Declarations}

Ethics approval and consent to participate

Not applicable.

\section{Consent for publication}

Not applicable.

\section{Competing interests}

The authors declare that they have no competing interests.

\section{Author details}

'Wildlife Ecology and Conservation, University of Florida, Gainesville, FL, USA.

${ }^{2}$ Forest Resources and Conservation, University of Florida, Gainesville, FL, USA.

Received: 15 December 2020 Accepted: 11 May 2021

Published online: 21 May 2021

\section{References}

Baccetti N, Cherubini G, Magnani A, Serra L. Homing performances of adult and immature Dunlins Calidris alpina (Aves Scolopacidae) displaced from their wintering area. Ethol Ecol Evol. 1995;7:257-64.

Baguette M, van Dyck H. Landscape connectivity and animal behavior: functional grain as a key determinant for dispersal. Landscape Ecol. 2007;22:1117-29

Baker MB, Rao S. Incremental costs and benefits shape natal dispersal: theory and example with Hemilepistus reaumuri. Ecology. 2004;85:1039-51.

Begon M, Howarth RW, Townsend CR. Essentials of ecology. Hoboken, NJ: Wiley; 2014

Bélisle M, Desrochers A, Fortin MJ. Influence of forest cover on the movements of forest birds: a homing experiment. Ecology. 2001;82:1893-904.

Benvenuti $S$, loalè P. Homing experiments with birds displaced from their wintering ground. J Ornithol. 1980;121:281-6.

Berner TO, Grubb TC Jr. An experimental analysis of mixed-species flocking in birds of deciduous woodland. Ecology. 1985;66:1229-36.

Blumstein DT, Fernández-Juricic E. A primer of conservation behavior. Sunderland: Sinauer Associates Inc: 2010

Brewer R. Comparative notes on the life history of the Carolina Chickadee. Wils Bull. 1961;73:348-73.

Brown JL. Aggressiveness, dominance and social organization in the Steller's Jay. Condor. 1963;65:460-84

Castellón TD, Sieving KE. An experimental test of matrix permeability and corridor use by an endemic understory bird. Conserv Biol. 2006;20:135-45

Chalfoun AD, Thompson FR III, Ratnaswamy MJ. Nest predators and fragmentation: a review and meta-analysis. Conserv Biol. 2002;16:306-18.

Condee RW. The winter territories of Tufted Titmice. Wils Bull. 1970:177-83.

Contreras TA, Sieving KE. Leadership of winter mixed-species flocks by Tufted Titmice (Baeolophus bicolor): are titmice passive nuclear species? Int J Zool. 2011;2011:670548.

Cornelius C, Awade M, Cândia-Gallardo C, Sieving KE, Metzger JP. Habitat fragmentation drives inter-population variation in dispersal behavior in a Neotropical rainforest bird. Perspect Ecol Conserv. 2017;15:3-9.

Crooks KR, Sanjayan M. Connectivity conservation. Cambridge: Cambridge University Press; 2006

Desrochers A, Hannon SJ. Gap crossing decisions by forest songbirds during the post-fledging period. Conserv Biol. 1997;11:1204-10.

Desrochers A, Hannon SJ, Nordin KE. Winter survival and territory acquisition in a northern population of Black-capped Chickadees. Auk. 1988:105:727-36.

Desrochers A, Bélisle M, Morand-Ferron J, Bourque J. Integrating GIS and homing experiments to study avian movement costs. Landscape Ecol. 2011:26:47-58

Duhl TR, Guenther A, Helmig D. Estimating urban vegetation cover fraction using Google Earth ${ }^{\circledR}$ images. J Land Use Sci. 2012;7:311-29.

Evans BS, Kilpatrick AM, Hurlbert AH, Marra pp. . Dispersal in the urban matrix: assessing the influence of landscape permeability on the settlement patterns of breeding songbirds. Front Ecol Evol. 2017;5:63.
Farley EA, Sieving KE, Contreras TA. Characterizing complex mixed-species bird flocks using an objective method for determining species participation. J Ornithol. 2008:149:451-68.

Gerber BD, Karpanty SM, Kelly MJ. Evaluating the potential biases in carnivore capture-recapture studies associated with the use of lure and varying density estimation techniques using photographic-sampling data of the Malagasy civet. Popul Ecol. 2012;54:43-54

Gillies CS, St Clair CC. Riparian corridors enhance movement of a forest specialist bird in fragmented tropical forest. P Natl Acad Sci. 2008;105:19774-9.

Gillies CS, Beyer HL, St Clair CC. Fine-scale movement decisions of tropical forest birds in a fragmented landscape. Ecol Appl. 2011;21:944-54.

Halkin SL, Linville SU. Northern Cardinal (Cardinalis cardinalis), version 1.0. In: Poole AF, Gill FB, editors. Birds of the World. Cornell Lab of Ornithology: Ithaca; 2020.

Hetrick SA, Sieving KE. Antipredator calls of tufted titmice and interspecific transfer of encoded threat information. Behav Ecol. 2012;23:83-92.

Hindmarch S, Elliott JE, Mccann S, Levesque P. Habitat use by barn owls across a rural to urban gradient and an assessment of stressors including, habitat loss, rodenticide exposure and road mortality. Landscape Urban Plan. 2017:164:132-43.

Holmes RT, Sherry TW, Reitsma L. Population structure, territoriality and overwinter survival of two migrant warbler species in Jamaica. Condor. 1989;91:545-61.

Hoover JP, Brittingham MC, Goodrich LJ. Effects of forest patch size on nesting success of wood thrushes. Auk. 1995:112:146-55.

Hostetler M. The importance of multi-scale analyses in avian habitat selection studies in urban environments. In: Marzluff JM, Bowman R, Donnelly R, editors. Avian ecology and conservation in an urbanizing world. Boston: Springer; 2001. p. 139-54.

Huang P, Kerman K, Sieving KE, St Mary CM. Evaluating the novel-environment test for measurement of exploration by bird species. J Ethol. 2016:34:45-51.

Jokimäki J, Huhta E. Artificial nest predation and abundance of birds along an urban gradient. Condor. 2000;102:838-47.

Jones CD, Stodola KW, Coombs J, Ward MP, Cooper RJ. Responses of Bachman's sparrows and prairie warblers to fragmentation. J Wildlife Manage. 2017:81:347-55.

Keiser JT, Ziegenfus CWS, Cristol DA. Homing success of migrant versus nonmigrant dark-eyed juncos (Junco hyemalis). Auk. 2005;122:608-17.

Koen EL, Tosa MI, Nielsen CK, Schauber EM. Does landscape connectivity shape local and global social network structure in white-tailed deer? PloS one. 2017:12:e0173570.

Krištín A, Kaňuch P. Stay or go? Strong winter feeding site fidelity in smal woodland passerines revealed by a homing experiment. J Ornithol. 2017:158:53-61.

Leitāo AB, Ahern J. Applying landscape ecological concepts and metrics in sustainable landscape planning. Landsc Urban Plan. 2002:59:65-93.

Lima SL. Ecological and evolutionary perspectives on escape from predatory attack: a survey of North American birds. Wils Bull. 1993:1-47.

Lima SL, Zollner PA. Towards a behavioral ecology of ecological landscapes. Trends Ecol Evol. 1996:11:131-5.

López-Flores V, MacGregor-Fors I, Schondube JE. Artificial nest predation along a Neotropical urban gradient. Landsc Urban Plan. 2009:92:90-5.

Malone KM, Powell AC, Hua F, Sieving KE. Bluebirds perceive prey switching by Cooper's hawks across an urban gradient and adjust reproductive effort. Ecoscience. 2017;24:21-31.

Metzger JP, Décamps $\mathrm{H}$. The structural connectivity threshold: an hypothesis in conservation biology at the landscape scale. Acta Oecol. 1997;18:1-12.

Miller JR, Cale P. Behavioral mechanisms and habitat use by birds in a fragmented agricultural landscape. Ecol Appl. 2000;10:1732-48.

Newbold T, Scharlemann JP, Butchart SH, Şekercioğlu ÇH, Alkemade R, Booth $H$, et al. Ecological traits affect the response of tropical forest bird species to land-use intensity. Proc R Soc B Biol Sci. 2013;280:20122131.

Norris DR, Stutchbury BJM. Extraterritorial movements of a forest songbird in a fragmented landscape. Conserv Biol. 2001;15:729-36.

Odum EP. Winter homing behavior of the chickadee. Bird-Banding. 1941:12:113-9.

Patterson L, Kalle R, Downs C. Predation of artificial bird nests in suburban gardens of KwaZulu-Natal South Africa. Urban Ecosyst. 2016;19:615-30.

Peterjohn BG. Agricultural landscapes: can they support healthy bird populations as well as farm products? Auk. 2003;120:14-9. 
Pimm SL, Brooks T. Conservation: forest fragments, facts, and fallacies. Curr Biol. 2013;23:R1098-101.

Pyle P. Identification guide to North American birds: a compendium of information on identifying, ageing, and sexing "near-passerines" and passerines in the hand. Bolinas, CA: Slate Creek Press; 1997.

Rail JF, Darveau M, Desrochers A, Huot J. Territorial responses of boreal forest birds to habitat gaps. Condor. 1997;99:976-80

Ritchison G, Omer MK. Winter behavior of Northern Cardinals (Cardinalis cardinalis). Trans Ky Acad Sci. 1990;51:145-53.

Ritchison G, Grubb TC, Pravosudov V. Tufted titmouse (Baeolophus bicolor), version 1.0. In: Rodewald PG, editor. Birds of the World. Cornell Lab of Ornithology: Ithaca; 2020.

Roth TC II, Vetter WE. The effect of feeder hotspots on the predictability and home range use of a small bird in winter. Ethology. 2008;1 14:398-404.

Roth TC II, Lima SL, Vetter WE. Determinants of predation risk in small wintering birds: the hawk's perspective. Behav Ecol Sociobiol. 2006;60:195-204.

Royle NJ. An introduction to behavioural ecology. In: Davies NB, Krebs JR, West SA, editors. Animal behaviour. Hoboken: Wiley; 2012. p. 686-7.

Salomonson MG, Balda RP. Winter territoriality of Townsend's Solitaires (Myadestes townsendi) in a pinon-juniper-ponderosa pine ecotone. Condor. 1977;79:148-61.

Schlaepfer MA, Runge MC, Sherman PW. Ecological and evolutionary traps. Trends Ecol Evol. 2002;17:474-80.

Shimazaki A, Yamaura Y, Senzaki M, Yabuhara Y, Nakamura F. Mobbing cal experiment suggests the enhancement of forest bird movement by tree cover in urban landscapes across seasons. Avian Conserv Ecol. 2017;12:6.

Sieving KE, Karr JR. Avian extinction and persistence mechanisms in lowland Panama. In: Laurence W, Bierregaard R, editors. Tropical forest remnants: ecology, management, and conservation of fragmented communities. Chicago: University of Chicago Press; 1997. p. 156-70.

Sieving KE, Willson MF, De Santo TL. Habitat barriers to movement of understory birds in fragmented south-temperate rainforest. Auk. 1996;113:944-9.

Sieving KE, Contreras TA, Maute KL. Heterospecific facilitation of forest-boundary crossing by mobbing understory birds in north-central Florida. Auk. 2004;121:738-51.
St Clair CC, Bélisle M, Desrochers A, Hannon S. Winter responses of forest birds to habitat corridors and gaps. Conserv Ecol. 1998;2:13.

Stratford JA, Stouffer PC. Local extinctions of terrestrial insectivorous birds in a fragmented landscape near Manaus. Brazil Conserv Biol. 1999;13:1416-23.

The Editors of Encyclopaedia Britannica. Homing. Encyclopedia Britannica. 2017. https://www.britannica.com/science/homing. Accessed 14 Dec 2020

Tompkins G. Individuality and territoriality as displayed in winter by three passerine species. Condor. 1933;35:98-106.

Valiela I, Martinetto P. Changes in bird abundance in eastern North America: urban sprawl and global footprint? Bioscience. 2007;57:360-70.

Vergara PM, Simonetti JA. Abundance and movement of understory birds in a Maulino forest fragmented by pine plantations. Biodivers Conserv. 2006;15:3937-47.

Villard MA, Haché S. Conifer plantations consistently act as barriers to movement in a deciduous forest songbird: a translocation experiment. Biol Conserv. 2012;155:33-7.

Volpe NL, Hadley AS, Robinson WD, Betts MG. Functional connectivity experiments reflect routine movement behavior of a tropical hummingbird species. Ecol Appl. 2014;24:2122-31.

Weisman RG. Ecology and behavior of chickadees and titmice: an integrated approach. In: Otter A, editor. The quarterly review of biology. Oxford, UK: Oxford University Press; 2007. p. 124-5.

With KA, King AW. Extinction thresholds for species in fractal landscapes. Conserv Biol. 1999;13:314-26

Wood EM, Esaian S. The importance of street trees to urban avifauna. Ecol Appl. 2020;30:e02149.

Yoder JM, Marschall EA, Swanson DA. The cost of dispersal: predation as a function of movement and site familiarity in ruffed grouse. Behav Ecol. 2004;15:469-76.

Zollner PA, Lima SL. Behavioral tradeoffs when dispersing across a patchy landscape. Oikos. 2005;108:219-30.
Ready to submit your research? Choose BMC and benefit from:

- fast, convenient online submission

- thorough peer review by experienced researchers in your field

- rapid publication on acceptance

- support for research data, including large and complex data types

- gold Open Access which fosters wider collaboration and increased citations

- maximum visibility for your research: over 100M website views per year

At BMC, research is always in progress.

Learn more biomedcentral.com/submissions 